The Tharu Women of Sukhrawar: The Status of Women in Nepal: vol.2, pt. 3, Kathmandu, CEDA. T.U.

RIDA

1991

UNICEF

1991
Research Inputs and Development Associates. The Status of the Girl Child in Nepal. Kathmandu: Author.

Hamra Chelibetiharu (our daughters). An Analysis of the Situation of Girl Children in Nepal. Kathmandu: Author.

\section{CULTURAL DIMENSION OF PASTURE RESOURCE MANAGEMENT IN NEPAL: A STUDY OF GUMBA SYSTEM OF THE NORTHWEST DOLPA}

\author{
Dhirendra B. Parajuli ${ }^{*}$
}

Along the evolution of human civilization, the agropastoral societies have developed a diverse set of resource management ranging from simple to complex. This is mainly because of intimate and intricate knowledge of local physical and socio-cultural environment. The simple pastoralim is based on seasonal mobility of stocking herds towards high and low elevations in terms of seasons. In the same way, the complex pastoralism regulates the herds' movement by strict formal schedules, restriction on numbers and type of animals, reserving or deferring pastures, assigning members to particular pastures and controlling the amount of time spent in one pasture (Nimar:1995:245).

The agro-pasturalists of Nepal Himalayas including the Dolpo practice diverse set of natural resource management systems and to a large extent that differ from the practice of other parts of the World and the Nepal Himalayas as well. In the last few decades, the herders of North-west Dolpo have been adopting the complex system of pasture resource management: However, that is not modern and run in an indigenous ways. Being guided by the Bonpo philosophy, the system is functional only to the Gumba area managed by the Lamas which is typical

\footnotetext{
Mr. Dhirendra B. Parajuli is the Assistant Lecturer at Department of Sociology/Anthropology, Patan Mulitple Campus, Patan Dhoka, Lalitpur The information used in this paper were collected in the year- 1998 for research entitled - indigenous system of Pasture Resource Management in Kunasa Area within the Shey Phoksundo National Park. This research was conducted for the People and Plant Initiatives (PPI) Himalayas Program and World Wide Fund for Nature (WWF) Nepal Program. Therefore, I acknowledge the institutions for providing the research opportunity
} 
in nature. Perhaps this system was first developed in the Tibetan platue bordering to Nepal Himalayas and entered into the territory of Nepal Himalayas along the people's seasonal migration with the migratory herding. Over the periods and generations, among others, the systems of migratory herding and pasture resource utilization practices became the part of culture of the local people in Nepal Himalayas. This has been a constituent and identical part of socio-economic and cultural life of people with substantial inter-linkage to the resource use, livelihood and the environment as a whole.

The Gumba area, located within the Shey Phokshundo National Park (SPNP) area of the Dolpa district, is one of a few areas of Nepal where the local knowledge based indigenous systems of pasture resource management pattern is found being practiced by the people of Bonpo culture in the Pugmo village, especially under the Gumba system. Having cultural determinism in pasture resource management, the study of Gumba system of this area, among many others, possess high sociological and anthropological significance. Therefore, based on the primary data, this paper has aimed at highlighting on how is the status of the pastures and sub-pastures of the Gumba area and how the people of the Pugmo village under the local cultural context of the Gumba system have been locally managing the pasture resource with reference to migratory herding and local practices of medicinal plants harvesting.

\section{Overview of the Study Area: Pugmo Village and the Gumba Area}

Pugmo village is the studied village, which is one of the major settlements of Phoksundo VDC within the SPNP. The village lies in the upper part of the lower Dolpa region at an elevation of $3000 \mathrm{~m}$. It is located in a steep, narrow valley of the Pugmo river which runs from upper Pumphu watershed of northwest aspect to lower area of south-east aspect. Despite. the steep slopes surrounding the village, the village area is flat enough and surrounded by a small area of terraced agricultural lands where one school and some monasteries are also present. The southnorth facing landscape of Gumbadanda, located just across the
Pugmo river and opposite of the village is covered with the dense forests of different tree species; Pine, Juniper, Spruce, Birch etc. In the winter season, the domestic herds are grazed within the forest grounds, pasture lands and agricultural terraces located around the village. Pugmo peoples' daily needs of timber, firewood and others forest products are fulfilled from the patches of forests lying in the homestead area. The hours of sunlight are short in the valley due to the steep sides and the wind is heavy during the day (Mcknight: 1997:13).

The village includes four wards of the Phoksundo VDC and has a total of 30 households. Moreover, this village contains a total of 159 inhabitants with 73 male and 86 female. All the people of the village are of Tibetan origin and are the followers of the Bonpo religion ${ }^{1}$. This village is not inhabited throughout the year because the people migrate to Koiru village, a secondary village, which lies at an hour up from Pugmo village for about two months during the peak of winter season. Such seasonal migration is their adaptive strategy for protecting themselves from the severe cold. Furthermore, a few families stay in Punikha and Gumba villages throughout the year whereas at least two individuals or herdsmen of almost each family seasonally stay at Kunasa and Pumphu areas for about five months in a year while grazing their livestock in the summer.

The village or villagers' economy is largely dependent on agro-pastoralism. Almost all the people are small farmers who have less land and that is also less productive as being steep sloped terraces and stony soil composition. Thus more than $80 \%$ households are under food deficiency by their year round production and they are highly relaying on the income derived from external sources: livestock raising and trans-Himalayan trade. The livestock raising is acknowledged as the backbone of their village economy that is based on high grazing practice on the pasturelands.

\footnotetext{
1 Bonpo religion is the pre-buddhist religion of Tibet. After the spread of Buddhism in Tibet, it was incorporated under the Buddhism. The Pugmo Buddhism in Tibet, it was incorporated under the Buddhism. The Pugmo present, the Dalai Lama recognizes it as being one of the sects (parts) of the Buddism.
} 
The Gumba area is one of the major aspects is managed by the people of the Pugmo village and it lies in the western side of the village, just across the Pugmo river. It encompasses thousands of hectares of land within the Pugmo village management area $^{2}$ (PVMA) including the Kunasa summer pasture and Pumer and Punikha winter pasture areas where the Pugmo people seasonally graze their herds, in some areas cultivate crops, and harvest various pasture products (medicinal plants, firewood, forage, timber, etc.) for their daily resources need. This area was also clearly defined with a certain territory spreading from the Gumbadanda and Pugmo khola in the east, Sellathuan lek in the west, Jardum lek in the north and Bhupa lek (south back of Bankal and Talgera pastures) in the south. The Lamas have reported that in the past this territory of Gumba area was much larger than the whole PVMA. The territory could not be well-controlled and managed in the succeeding years of its demarcation and thus gradually lost. ${ }^{3}$

At present, in Gumbadanda, the focal point of the area, there are three Gumbas (monstries) named as: Youngdungchhungmo, Tasheding, and Tshekchhing-rakkaling. Of these, the later one is communally owned and is the village Gumba

2 The are which is traditionally demarcated by the Pugmo people for the pasture/forest and other natural resources use is referred here as the Pugmo village management area. It includes a wide range spreading from Sunduwa, Kuma, and Karbo pastures in the east, Kunasa valley (Kagmara lek, Sellathuan lek, Yambo Singlathuan Himals) in the west, upper Pumphu valley (white, black, and blue lakes), Perinakpo and Jousbatha pastures in the north and Bhupa lek in the South. Within this PVMA, the Gumba area is one aspect, smaller in size and located in the North-west sides.

3 Previously, in the time of first Lama- Teton Sikyal Sangbo, the Gumba managed area was wide spread including the places; Tripurakot, Kaigoan, Jagdulla, Bagala, Medok la (way to Shey Gumba), Chhokarpo (inside Pumphu) and Suligad. At the time of 5th Lama Thungton Namgyal Scrap Gyaljan, this territory remained only areas; Phaparbari, Polam, Pungphu, Jaralung lek and Sellathuan lek. Similarly at his time, except for Gumba (present Gumba area), and Sumduwa all other areas were gradually lost. In the same way at the time of the great grand father of present Lama (Shree Lama) Sumduwa was lost and only the present village management area remained and the area was again separated as village management area and Gumba area along with the inception of Talukdari system in the Pugmo village area. (monastery) and the former two are individually owned, therefore, are private Gumbas. But within the Gumba area, there are a total of 9 Gumbas situated in different places and ownership title. The Tabas, and nuns are rotated in each Gumbas for both educational and religious purposes where the Lamas provide different kinds of knowledge to them about the resources, environment and the Bonpo religious philosophy. Thus the area is known as a 'holy land' or 'Lama land' managed by the Lamas of Bonpo religion follower where killing of any domestic animals and wildlife species is considered as sinful and thus strictly prohibited. In this area, the Lamas with special involvement of local people operate year-round religious and educational activities. Besides, the Lamas have been controlling and maintaining the land and other natural resources: forests and pasture in this area over the generations.

\section{History of Pasture Resource Management Under in the Gumba Area}

Nobody knows the antiquity of human settlement in the Pugmo area, as authentic historical studies are not available. The available facts reveal that the history of this area dates back 1000 years (Miller: 1993:a). Perhaps since that time or before the area might have been inhabited by the people belonging to Tibetan ethnicity. The Pugmo people particularly know that their ancestors of $10^{\text {th }}$ generation back had lived in the area. ${ }^{4}$ So the history of pasture resource management of this area can be associated with the history of settlement of the Lamas. The Lamas were not only religious heads and most knowledgeable people in the society but also dynamic agro-pasturalists and Trans-Himalayan traders. In course of that, they had traveled all accessible nooks and corners of the area and gained the precise knowledge of geo-physical structure, climate, resources and the local environment as a whole. On the other hand, the Lamas

\footnotetext{
4 The name of late Lama lineage heads include: Teatton Sikyal Sambo, Tetton Chhewalg Chhuldin, Tetton Mollam Gyaljan, Tetton Namkha Gyaljan, Thungton Namgyal Scrap Gyaljan, Thengton Gekor Rinchhen Gyatjan, Thungton Serap Nyima, .... and Grand Father + Father of Shree Lama (present Lama).
} 
under the Gumba system have been controlling and managing the land and other natural resources. Therefore, the pattern of pasture resources management is found attached with the history of Bonpo cultural development, pertaining knowledge of the Lamas and changing experiences of historical phases.

In this study the Gumba System of resources management has been taken here as the system of control and operational management of natural resources by the Lamas who reside in the Gumbadanda of Pugmo village. Perhaps this is the typical system common in the Phoksundo VDC and Nepal Himalaya, which is based on the philosophy of Bonpoism. Initially, the system was so simple that the Lamas used to control and manage the resource, collect the nominal royalty in the form of cash and kinds from the users of resources and fine from the encroachers of forest and agricultural-lands. They used the collected cash, grains, etc in the religious activities that used to take place in the Pugmo village. But later on, the Lama Tetton Molan Gyaljan (Lama of $3^{\text {rd }}$ generation) had made the system more systematic with new arrangements of rules (Chapter: 3.4) and Lama hierarchic system with attributed responsibilities for the control and operational management of resources, which can be observed in the Table 1 given below:

Table 1: Lama Hierarchic System and Attributed Responsibilities to Each Hierarchy

\begin{tabular}{|c|c|c|c|c|}
\hline SN & $\begin{array}{c}\text { Lama } \\
\text { Hierarchy }\end{array}$ & Status & Numbe & Major Responsibilities \\
\hline 1. & $\begin{array}{l}\text { Chhabi } \\
\text { Lama }\end{array}$ & Main Lama & One & $\begin{array}{l}\text { The overall responsibilities of } \\
\text { religious activities and control } \\
\text { and operational management of } \\
\text { land and other resources: forest } \\
\text { and pasture. }\end{array}$ \\
\hline 2. & $\begin{array}{l}\text { Lajung } \\
\text { Lama }\end{array}$ & $\begin{array}{l}\text { Assistant } \\
\text { Lama }\end{array}$ & One & $\begin{array}{l}\text { To assist main Lama in his } \\
\text { tasks regarding the natural } \\
\text { resource management and } \\
\text { religion. }\end{array}$ \\
\hline 3. & $\begin{array}{l}\text { Kerkha } \\
\text { Lama }\end{array}$ & $\begin{array}{l}\text { Junior } \\
\text { Lama }\end{array}$ & One & $\begin{array}{l}\text { To assist main Lama and } \\
\text { assistant Lama in their tasks } \\
\text { identified already. }\end{array}$ \\
\hline 4. & Tabas & $\begin{array}{l}\text { (Beginner } \\
\text { Students/A } \\
\text { ssistants) }\end{array}$ & $\underset{*}{\operatorname{Many}}$ & $\begin{array}{l}\text { To assist all senior Lamas in } \\
\text { religious and natural resources } \\
\text { management activities. }\end{array}$ \\
\hline
\end{tabular}

* There were 16 Tabas in the Gumba area during the field study.
The hierarchic system revealed that the Lamas were the people having higher status in the community. Of them, the main Lama occupied the most respected position with higher responsibilities followed by the junior, assistant Lamas and Tabas. Such responsibilities and status were meaningfully attributed to the senior Lamas as they were the most educated and knowledgeable people as compared to other junior Lamas. The main Lama was primarily responsible for public health care, religious functions, public education, conflict resolution, public security, resource regulation and management, Gumba management, construction and repair of bridges and beaten tracks. Past experiences revealed that the Lamas performed their responsibilities in such an effective way that there were no complaints in their tasks, duties and decisions. However, in course of performing their responsibilities, Lamas used to control public land encroachment by people, firing in the forests and pasturelands, tree felling, haphazard rotation of herds in the seasonal grazing pasture, commercial pasture product harvesting, outsiders encroachment and wildlife poaching within their territory. Similarly, other Lamas and Tabas were generally responsible to assist main Lama while performing all the responsibilities. Apart from these, the assistant and junior Lamas had additional responsibilities of handling the whole natural resource control and management system and performing all other responsibilities of main Lama in his absence.

This system was not formal and officially attributed to them but was of local level, mainly based on the Lamas' pertaining knowledge guided by the Bonpo culture and past experiences. Thus, controlled from Gumbadanda monastery, this system was commonly effective in the very past in the Pugmo village and entire Pugmo village management area. However, along with the extension of Talukdari system and District Land Tax Office (Mal Adda) after 1911 A.D, this system became confined only in the Gumba area. Thereafter, local revenue 
collection rights were transferred to the Mukhiya even in Gumba area (Phu, Punikha, Gumba and Kunasa agricultural lands).

Even after the establishment of SPNP, the park policy has guaranteed indigenous peoples' use rights on land, forest and pastures. But, only a few old traditions like Lamas' authority of granting permission for harvesting timber has shifted to the park authority. Similarly, timber product export to outside the park boundary was completely checked. However, all other regulations of old Gumba system are existed even today. Thus, the grazing and pasture product harvesting practices for household needs within the park area including the Gumba area are smoothly going on as previously.

\section{Management Pattern of Pasture Resource Under the Gumba System}

The Indigenous system of rangeland or pastureland management includes various aspects or techniques such as rotational grazing, deferred grazing, plant and animal performance indicators, carrying capacity estimation and livestock number reduction, etc., which are also common in western (European) range management. But in the east (Asia), these aspects or techniques, however, are not adopted in the same way as they are in the west. In the context of Nepal, indigenous rangeland or pasture resource management system relies on common senses, habits and traditions developed by the resource users of preceding generations and handed to the subsequent generations (Parajuli, 1996: 25). In some areas, cultural and religious influences become more detrimental and more effective than the system or practices of any other areas. Keeping these things in mind, indigenous management system of pasture resources in Kunasa area that is mainly guided under the Gumba system of the Bonpo religious culture was examined with common senses, traditions, habits and practices which includes; status inventory, resource allocation, consumption pattern, existing operational rules, decision making, labor mobilization and conflict resolution process.

\section{Status of Gumba Area Pasture and Sub-Pastures}

Within the Gumba area, the Kunasa is the largest and major summer pasture that is seasonally utilized by the herders of the Pugmo village including the Punikha, Pumar and Gumba village. It is a typical pasture with agricultural land in the high altitude area. Historically, it was only the place where herds and herders used to reside in the plain ground in the night, in the temporary shelters but over the generations, with changing time and increasing demand for agricultural lands, the herdsmen not only constructed permanent houses of stone structure but also extended the flat area as the cropping land. At present, the name Kunasa is of great meaning as it describes both an area and a specific place. The specific place indicates the agricultural land and the settlement areas: Pandang and Lhaye including the nearby grazing grounds. Similarly, the Kunasa area indicates the collection of many pasturelands and their grazing units, adjoining forests, rocky slopes and snowing mountains in the upper Kunasa Khola watershed. However, the specific Kunasa place is not only the settlement area with agriculture land but also the central point of other neighboring pasturelands from where the rotational grazing and pasture harvesting activities are particularly operated. It is, therefore, the herdsmen who have classified the specific Kunasa place including nearby grazing units as the main pasture and other adjoining pasturelands with semi-permanent shelters as the sub-pastures. Based on their classification, in this study also, the status inventory information of Kunasa pasture and sub-pastures (Bankal, Talgera, Kungathang and Pangjauwa) of the Gumba area can be stated in a tabular form as follows: 
Table 2. Status of the Pastures, Sub-pastures and Grazing Units of the Gumba Area

\begin{tabular}{|c|c|c|c|c|c|c|}
\hline $\begin{array}{l}\text { Pastures } \\
\& \text { sub- } \\
\text { pastures }\end{array}$ & EAH & $\begin{array}{c}\text { Alt. } \\
\text { Range }\end{array}$ & $\mathrm{SD}^{1}$ & $\mathrm{SD}^{2}$ & Category & Name of the grazing units \\
\hline $\begin{array}{l}\text { Kunasa } \\
\text { Proper }\end{array}$ & 75 & $\begin{array}{l}3900- \\
4100\end{array}$ & $5-10$ & $\begin{array}{c}\text { W-E } \\
\& \\
\text { N-S }\end{array}$ & $\begin{array}{l}\text { Summer } \\
\text { Pasture }\end{array}$ & $\begin{array}{l}\text { Chemjunlgthang, Baijangthang, } \\
\text { Rukduithang, Tsmjungthang, } \\
\text { Pangdangthang, Lhai-thang, } \\
\text { Pangjauwa ridge, Urjukthang, } \\
\text { Ghoyour. }\end{array}$ \\
\hline $\begin{array}{l}\text { Kyungat } \\
\text { hang }\end{array}$ & 100 & $\begin{array}{l}4000- \\
5000\end{array}$ & $5-15$ & W-E & $\begin{array}{l}\text { Summer } \\
\text { Pasture }\end{array}$ & $\begin{array}{l}\text { Leju, Thendi, Rapka, Guttingtong, } \\
\text { Uralba, Rugdui, Chhalchhap, } \\
\text { Tsumik, Ngyabo-chhya, Ngyabo- } \\
\text { choyne, Dhupuk-mumba, } \\
\text { Dhupuk-taptap, Korbothang, } \\
\text { Thalachhusya, Behu, Sahuche, } \\
\text { Ngingtong, Tsumik-ringmo. }\end{array}$ \\
\hline Talgera & 120 & $\begin{array}{l}3900- \\
4500\end{array}$ & $5-15$ & $\mathrm{~S}-\mathrm{N}$ & $\begin{array}{l}\text { Summer } \\
\text { Pasture }\end{array}$ & $\begin{array}{l}\text { Chairi, Tharchang, Talgera } \\
\text { proper, Talgera Lhai, Langdang, } \\
\text { Thansam, Khogmochhe, Taktak- } \\
\text { kogma, Taktak-hogma, Japan- } \\
\text { tima-khasa, Kappataitung, Rugdi }\end{array}$ \\
\hline $\begin{array}{l}\text { Pangjau } \\
\text { wa }\end{array}$ & 250 & $\begin{array}{l}4300- \\
5000\end{array}$ & $5-15$ & $\mathrm{~N}-\mathrm{S}$ & $\begin{array}{l}\text { Summer } \\
\text { Pasture }\end{array}$ & $\begin{array}{l}\text { Lama Chumik kogma, Lama } \\
\text { Chumik hogma, Soitoriya, } \\
\text { Ngingri, Baijangthang, Beritong, } \\
\text { Ngingtong, Dharaksawa, } \\
\text { Lhaititang, Pangjauwa proper, } \\
\text { Pangiauwa Lhai, Madalthang, } \\
\text { Penhri-chhemu, Yamahiulsa, } \\
\text { Yujajang, Upper Ghoyur, } \\
\text { Suibutong, Lewer Ghoyur, Urjuk. }\end{array}$ \\
\hline Bankal & 130 & $\begin{array}{c}3800- \\
4500\end{array}$ & $5-15$ & $\mathrm{~S}-\mathrm{N}$ & $\begin{array}{l}\text { Summer } \\
\text { Pasture }\end{array}$ & $\begin{array}{l}\text { Phusingtong-hogma, } \\
\text { Phusingtong-kogma, Pangpho, } \\
\text { Dhawopenhri, Uiri, Chhulung, } \\
\text { Lhai-kogma, Lhai-hogma, } \\
\text { Laundanda, Taksep, Buksep, } \\
\text { Thangsep, Chhoijom-ngyaltsa, } \\
\text { Saun-kogma, Saunparma, Saun- } \\
\text { hogma. }\end{array}$ \\
\hline Punikha & 100 & $\begin{array}{l}3600- \\
4300\end{array}$ & $\begin{array}{l}10- \\
20\end{array}$ & $\begin{array}{c}\text { N-S } \\
\& \\
W-E\end{array}$ & $\begin{array}{l}\text { Winter } \\
\text { Pasture }\end{array}$ & $\begin{array}{l}\text { Ghyamlung, Shugri Nyishar } \\
\text { gomba, Pho gomba, Takpakogma, } \\
\text { Sittihi, Pholtak. }\end{array}$ \\
\hline Pumer & 50 & $\begin{array}{l}3500- \\
4000\end{array}$ & $\begin{array}{l}10- \\
20\end{array}$ & $\mathrm{~N}-\mathrm{S}$ & $\begin{array}{l}\text { Winter } \\
\text { Pasture }\end{array}$ & $\begin{array}{l}\text { Sikyal penhri, Nihma suhsa, } \\
\text { Settonh penhri, Dhangak, } \\
\text { Penhridhunh, Shukpajongjong, } \\
\text { Solajosa, Sittige, Dhonwabesa. }\end{array}$ \\
\hline
\end{tabular}

Source : Field survey, June 1998

Note $: \mathrm{EAH}=$ Estimated Area in Hectare, Alt. $=$ Altitude, $\mathrm{SD}^{1}=$ Slope Degree, $\mathrm{SD}^{2}=$

Slope Direction, $\mathrm{W}-\mathrm{E}=$ West-East, $\mathrm{E}-\mathrm{W}=$ East-West, $\mathrm{S}-\mathrm{N}=$ South-North, $\mathrm{N}-\mathrm{S}=$ NorthSouth

As presented in the table above, the Kunasa pasture and its sub-pasture of Gumba area are located above $3500 \mathrm{~m}$. and spread to $5000 \mathrm{~m}$. Almost all these pastures are of large size with more than 100 hectare grazing lands. On an average, the slope degree of the Goths residing parts of the pastures and subpastures range between 5-20 degree but adjoining grazing grounds are more sloped upto 60 degree. The slope direction is similar to that of other high altitude of Nepal that the pastures are S-N, N-S, E-W, and W-E faced. Each sub-pastures contain more than 10 grazing units which are the core livestock grazing areas named either culturally or on the basis of gro-physical structure of the pastures. Except for the winter pastures: Punikha and Pumer, all others are the aspects (sub-pastures) of the Kunasa summer pasture.

So far as the matter of grazing intensity and forage status of the Kunasa pasture and sub-pastures of the Gumba area is concerned, there is high grazing intensity in the main Kunasa pasture (Kunasa Proper) as the herds are grazed there intensively in June and October, the periods of entry and exit, respectively. But in other sub-pastures grazing is not so intensive and pastures' forage status is relatively good as the pastures are deferred more than 10 months each year and the herds do not remain and graze so intensively. These sub-pastures are rich for medicinally and commercially valuable plants like Bhultey, Yarshagumba, Sunpate, Katuko, etc. especially in the rocky slopes of the grazing units, so grazing movements of livestock is not much harmful for the regeneration and growth of these plants. Similarly, fodder grasses of different species are abundant in these sub-pastures, thus the carrying capacity of them is relatively high. These pastures and sub-pastures are utilized by the herders in various ways.

\section{Pasture Resource Utilization Pattern Within the Gumba Area}

The utilization pattern of pasture resource is guided under its allocation practice, which includes both individual and communal modes. In individually owned lands of the Pumer, 
Punikha, and the Kanasa areas individual resource allocation is present whereas in common pasture areas, the communal system of resource allocation is found. Accordingly, pastures resource utilization patterns is guided in this area which can be characterized as a complex set and that includes two major ways: rotational and deferred grazing, and pasture harvesting. This pattern differs from pasture to pasture and therefore is described here with reference to sub-pastures also.

\section{Rotational and Deferred Grazing}

The livestock grazing is the most common mode of pasture resource consumption in the area. The livestock species such as yak, chauri, cattle, goats, horses, etc, are mainly raised under high altitude grazing system. The transhumance, this system includes grazing of livestock in the higher elevation during the summer season and grazing in the lower elevation during the winter season. Within the Gumba area, the Kunasa and its sub pastures are the summer pastures whereas cropping fields, forests and pastures of homestead areas of Pugmo, Pumer, Punikha, and Gumba villages are the winter pastures. Except the Pugmo villages all others are located within the Gumba area. Mainly, yak, chauri and cattle are the livestock species, grazed in the summer pastures whereas along with these livestock, goats and horses are included and grazed in the winter pastures. A total of 442 livestock of different species are raised by 27 households of these villages commonly known as the Pugmo herders. Only 3 households of these villages are do not have livestock -less. The herders of 21 households of the Kunasa group which utilizes the Gumba area pastures have 206 livestock of different species including yak, chauri, cattle, etc., representing 7.63 livestock per household. Over generations, for systematic and sustainable grazing in the summer pastures, the people of the Gumba area have been maintaining an unique systems of rotational and deferred grazing especially in the Kunasa summer pasture and its sub-pastures of the Gumba area which can better be understood under different phases: first, second and third.

Shortly after the completion of 6-7 months' grazing practice in the winter pastures, the first phase of grazing in the summer pasture startes generally at the beginning of June. The cropping activities are almost completed at that time and the seasonal herders move to the Kunasa pasture areas with their herds and essential food materials. Under mutual understanding among the herdsmen, the date to follow the route to Kunasa pasture is decided and they generally reach there on the same day. While grazing their livestock at the Kunasa, the households are again segmented into two groups known as Lhaye and Pangdang groups which are formed representing the upper and lower Kunasa settlements, respectively. Following their own areas, the herds are mainly grazed in the peripheral grazing units of the Kunasa pasture rather than in the cropping land as it is closed for livestock grazing until harvesting of cultivated crops (mustard, wheat, barely and potato) in October. The herds of Lhaye group are grazed on various grazing units; Mathlloghoyour, Lhayathang, Chhulungthang, Baijangthang and Panjauwaridge, located above the Kunasa agricultural land and the settlement area. Similarly, the herds of the Pangdang group are primarily grazed on other grazing units such as Chemjungthang, Pangdangthang, Tsumjungthang and Kulysathang located just below the settlement area. While grazing in Kunasa pasture, all other sub-pastures are generally closed or restricted for grazing during the month of June ${ }^{5}$. Before the departure to other sub-pastures in June, the herdsmen and Lamas perform 'Kyulsa Puja' (worship) for the betterment of

\footnotetext{
Such grazing restrictions on pasture and sub-pastures are general norms (but not so sharp) because there is the lack of safe boundary between the subpastures, the herds sometimes enter into the restricted territory. In occasional cases, there is no system of punishment to the herders but the herdsmen are fined as rule breachers if they graze their livestock there intentionally ignoring their traditions.
} 
pasture land, climate, livestock and herdsmen's health, social unity and against the evil eyes in these regards. Such division of grazing areas are divided into two groups and cultural association to the resources seem more scientific in terms of pasture resource allocation for livestock grazing and social cohesion. These traditions are not only systematic and sustainable but also represent the pertaining knowledge of pasture resource management in a conflict-less and religious ways. The livestock grazing time schedule is similar to that of other high altitude areas in Nepal's northern belt and is mainly during the daytime. In the morning, the livestock are chased outside in the peripheral grazing units and in the evening brought back to keep in the temporary sheds. In Kunasa pasture, livestock are grazed for about one month especially during June.

Similarly, the second phase of the rotational grazing in Kunasa area starts along with the movement of livestock Goths from Kunasa pasture to the sub-pastures, Bankal and Talgera, in the early July. Thereafter, Kunasa pasture and sub-pastures like Kungathang and Pangjauwa are restricted for grazing as the herds cannot remain there as per the traditional grazing norms. The groups formed earlier are still maintained and accordingly the herds are driven to the sub-pastures following their own traditional routes. The herds of 'Pangdang group' are directly taken to the Bankal sub-pasture and grazed in its various grazing units. In the same way, the herds of 'Lhaye group' are taken to the Talgera sub-pasture and grazed in its grazing units. The daytime grazing and the nighttime residing in the sheds is also common there. But, the period of stay of livestock Goths in these sub-pastures depends upon the carrying capacity of each. However, these two sub-pastures having similar area and carrying capacity can carry out the pressure of livestock grazing for about one month during July. Then one grazing cycle within sub-pastures - Bankal and Talgera is completed with the movement of livestock Goths to other neighboring sub-pastures; Kungathang and Pangjauwa.
When the herds reach Pangjauwa from Talgera and Kungathang from Bankal, another grazing cycle within subpasture level begins. Then, Talgera and Bankal sub-pastures are closed for grazing because all the herds are to be shifted form there in order to avoid the over-grazing problem. The herds are grazed in the various grazing units of these newly shifted subpastures. The herdsmen and livestock reside in sheds and grazing patterns are similar to those of Bankal and Talgera sub-pastures. About one and half month is spent in course of grazing the livestock in these sub-pastures as almost all the grazing units are relatively richer in fodder grass composition than in the former Bankal and Talgera sub-pastures.

After the completion of the second phase, the third phase of rotational and deferred grazing begins with the movement of livestock Goths to the Kunasa homestead area/pasture, in the mid-September. Beside grazing in the peripheral grazing units of the Kunasa pasture, the herds at this time are additionally allowed to be grazed in cropping lands and the lower Ghoyour which is restricted from the very beginning of summer grazing (about 5 months in a year), especially from early May to the end of September for wild Garlick and fodder grass harvesting. Moreover, before descending from Kunasa, in the late October, the herds are also grazed for a few days in various grazing units of Pangsung pasture land which is located in the eastern side of Kunasa pasture on the route to Punikha and just opposite of the Talgera sub-pasture. Then downward Goth movement to the Pugmo village is made effective by the mid-October. In this way, the rotational grazing cycle in the Kunasa summer pasture and sub-pastures is completed till the next summer season. However, for better conceptualization a schematic diagram of rotational grazing system is given below in the Fig. 1. 
Figure 1: A Schematic Chart of Rotational Grazing System in Kunasa Pasture and Sub-pastures of the Gumba Area.

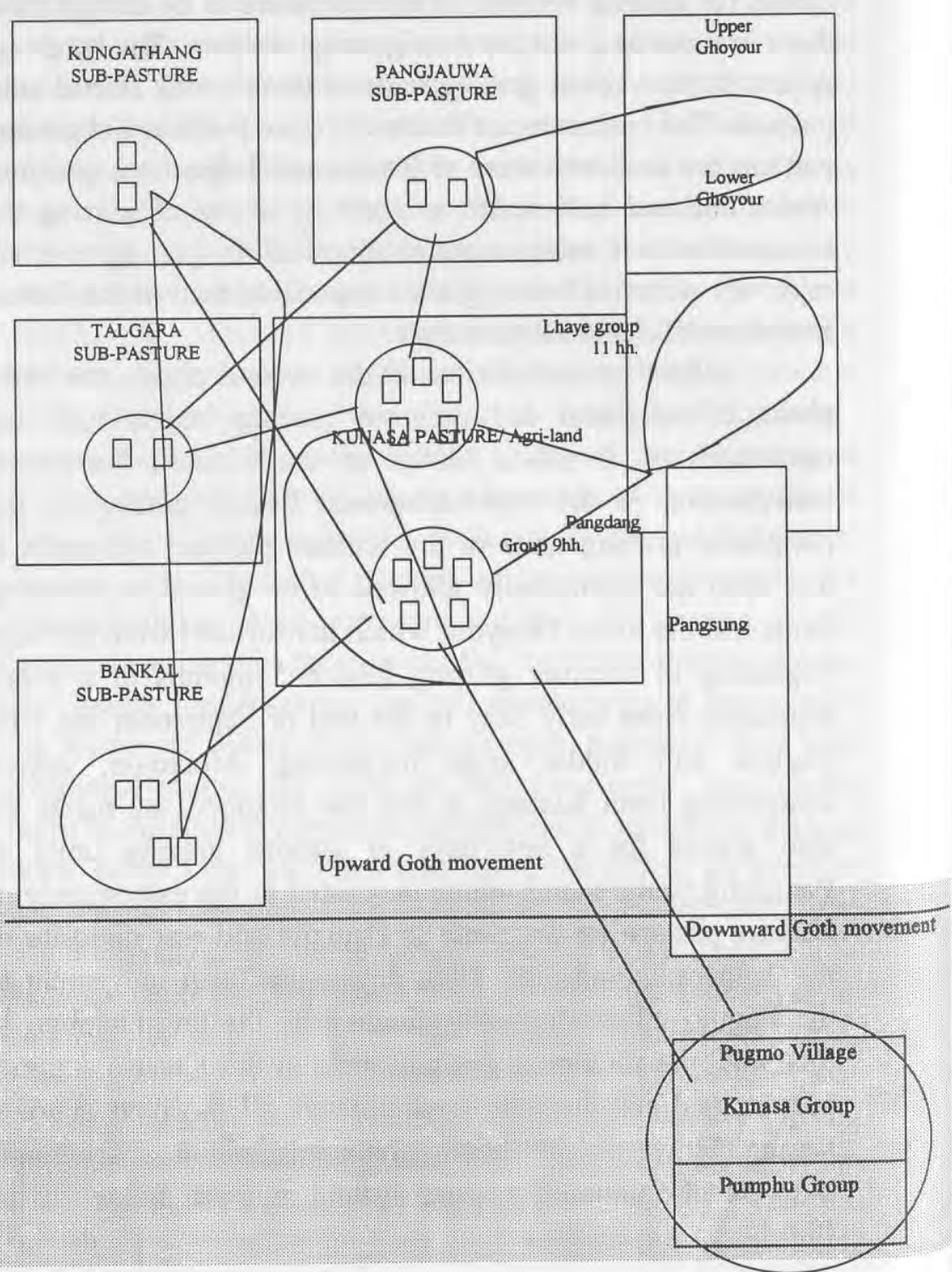

\section{Pasture Harvesting}

Unlike grazing the pasture harvesting is another way of pasture resource consumption, which is mainly concerned with various livestock and human needs including the healthcare. Collection of various pasture products: firewood, fodder grass, thatching materials, animal bedding and medicinal plants are some indicative ways of pasture harvesting. These ways also contain with their own methods, time period, significance, etc., and accordingly local Amchis and people of this area do both the harvesting. It is mainly based on the rules of the Bonpo culture (Section 3.4) and regulated as well as maintained by the Lamas under the Gumba system as a whole. A detailed view of the traditional cultural dimension on methods and ways of pasture consumption by harvesting the pasture products is given below.

\section{Medicinal Plant Harvesting}

Medicinal plant collection from the high-elevated pastures is the most popular mode of pasture harvesting. It concerns both livestock as well as human health. Because modern health facilities are lacked in the village and people are dependent on medicinal plant based on treatment system. However, inside the park collection of medicinal plants for commercial purpose is prohibited. Since with the granted use rights of the resources for home consumption, the harvesting of medicinal plants from the pastures and sub-pastures is common even after the establishment of SPNP. The people and Amchis have their own knowledge and traditions of harvesting various medicinal plants from the different pasture lands; Kunasa, Bankal, Talgera, Kungathang, Pangjawa and others. They also know the medicinal properties of hundreds of plant species found in the area, out of them, Sunpate (Rhododendron anthopogan), Katuko (Picrorhiza schrophulariiflora), Bhultey (Nardostachys grandiflora) and Yartsagumbo (Cordyceps sinensis), are some medicinally and commercially valuable plant species. Mainly, there appears a good and varied distribution pattern of these plants in the summer pastures of this area including in Kunasa pasture and its sub-pastures. The general people often harvest the plant indiscriminately which is not a 
sustainable way of harvesting. But this study reveals that Lamas/Amchis follow many sustainable ways of harvesting the medicinal plants and plant parts. They, sometimes, also guide general people about the rules and ways of sustainable medicinal plant harvesting which are based on the Tibetan calendar and medicinal texts.

Certain cultural processes regulate the harvesting time of various medicinal plants in this Lama managed area. The specific auspicious period is already determined according to the Tibetan medicinal text and calendar that is informed to the public by the Lamas. The 'Thanshing Richi' is the specific period of three days in which nutritional rainfall is believed to occur and then medicinal plants including fodder grasses are supposed to be well nourished by the rain-fed water. Thereafter, the medicinal efficiency of various plants is relatively higher than earlier and later periods or stages. Therefore, general people and Amchis of this area harvest medicinal plants only after the 'Thanshing Richi'. In this regard, it is to be noted that prior to the collection of medicinal plants, the Lamas perform a ritual, namely, 'Menlha Puja', which is made by two words; 'Men' (Medicine) and Lha (God). Etymologically, it means the Puja (worship) of the Medicine God (Buddha). The Lamas have also reported that in other areas of upper Dolpo like Bijer, Saldang, Karang, Birija, Komachhi, Namtor, Dho-Tharap, Chharka, Barpong, Kingdu and Tibetan pleatue, the local Amchis harvest medicinal herbs after the period of 'Thanshing Richi' and also perform the 'Menlha Puja'. Sometimes, Amchis also employ horses in harvesting the medicinal herbs, to maximize their activity during the peak maturity of the plants and plant parts. But this case is not applicable to all plants or plant parts which may be harvest far before or after the 'Thanshing Richi'.

The Pugmo people have their own harvesting techniques for various medicinal herbs. Generally, uprooting, cutting, picking, collecting, washing, drying (sunlight + shadow) and packing are the common techniques that have been adopted by the Pugmo people. If the roots of plants are medicinally valuable, uprooting is done when other parts; bark, seeds, fruit, flower, wood, leaves, etc., are needed; Collecting, cutting and picking ways are generally adopted which differ in terms of species, plant parts, and time. However, for the better examination of the tradition of medicinal herbs harvesting, a detailed information about the harvesting.ways of different plant parts, ways and time for each was obtained and is presented in the Table 3.

Table 3: Traditional Techniques and Ways of Medicinal Herbs Harvesting Pattern.

\begin{tabular}{|c|c|c|c|}
\hline S.N & $\begin{array}{l}\text { Plants/ } \\
\text { Plant parts }\end{array}$ & $\begin{array}{l}\text { Traditional ways of extraction for } \\
\text { harvesting }\end{array}$ & $\begin{array}{l}\text { Harvesting } \\
\text { time(months) }\end{array}$ \\
\hline 1 & Roots & $\begin{array}{l}\text { Uprooting: From the area where the } \\
\text { plants are dominant }\end{array}$ & Late Oct. \\
\hline 2 & Wood & $\begin{array}{l}\text { Cutting: From the trees in which } \\
\text { branches are thick and the } \\
\text { area where the trees are } \\
\text { dominant }\end{array}$ & Jan.-Feb. \\
\hline 3 & Bark & $\begin{array}{l}\text { Picking: From the large \& matured } \\
\text { trees with good interval } \\
\text { between each branches. }\end{array}$ & Mar.-Apr. \\
\hline 4 & Leaves & $\begin{array}{l}\text { Picking: From matured cluster of } \\
\text { leaves with certain interval in } \\
\text { each branches. }\end{array}$ & Early May \\
\hline 5 & Fruit & $\begin{array}{l}\text { Picking: From matured cluster of fruit } \\
\text { with certain interval in each } \\
\text { branches. }\end{array}$ & June and Oct. \\
\hline 6 & Flowers & $\begin{array}{l}\text { Picking: From the matured trees } \\
\text { where are dominant (less } \\
\text { than } 50 \% \text { of the total) }\end{array}$ & June-July \\
\hline 7 & Seeds & $\begin{array}{l}\text { Collecting : From trees in which } \\
\text { matured seeds are seasonally } \\
\text { available. }\end{array}$ & Sept.-Oct. \\
\hline \multicolumn{4}{|c|}{$\begin{array}{l}\text { There: Field survey, June, } 1998 \\
\text { medicinal plants or plant parts. Generally, the extracted herbs are } \\
\text { washed and put in a clean place to dry. But the methods or ways } \\
\text { of drying vary in terms of use category of the particular } \\
\text { medicinal herbs. First of all, the collected medicinal herbs are } \\
\text { identified and categorized as the herbs used in the cold and hot / } \\
\text { temperature related disease or problems. If the herbs fall in the } \\
\text { category of use for the cold related problems/diseases, are locally } \\
\text { called as 'Tangba' and generally dried in sunlight. Similarly, if } \\
\text { the herbs fall in the category of use for hot / temperature related } \\
\text { problems/disease are locally called as 'Chhaba' and are dried in }\end{array}$} \\
\hline
\end{tabular}


shadow. The Lamas have also reported that outside these two categories of diseases or problems, the herbs are generally dried both in sunlight and shadow with certain alternatives. While drying in sunlight and shadow, a crucial attention is paid towards the ventilation need and the herbs are kept in a well-ventilated condition. And only then the herbs are packed or stored.

\section{Fodder Harvesting}

The fodder harvesting includes both fodder grass and fodder leaves from the pastures and forests, respectively. This is the common mode of pasture harvesting concerned to the seasonal domestic livestock feeding practice. The pattern of fodder leaves harvesting is not so common here as the fodder trees are very nominal whereas the fodder grass harvesting is common but generally of small quantity and less intensive as the livestock raising system in this area is mostly based on grazing rather than stall feeding. The fodder grass harvesting is done to meet the needs of forage to feed the livestock during rainy days and intensive cropping days in the summer season. In general, a total of 5-10 Bhari (Weight of about $40 \mathrm{~kg}$ ) fodder grass is harvested by each households. Lower Ghoyour, Purungchhang and Pangsung are the main pasture lands for fodder grass harvesting which are left ungrazed and restricted for immature fodder harvesting. Also in other sub-pastures; Talgera and Pangjauwa, fodder grass is harvested only from the steep slopes where fodder grass is abundant but the site is not accessible for livestock. The harvesting is done mainly on individual family basis but at the same date and time jointly announced by the Mukhiya and Lamas. Like medicinal plant harvesting, this practice is also generally held in late September or October, especially after the 'Thansing Richi' of the Tibetan calendar. Similar harvesting of fodder grass is done even in the cropping lands and pastures of Punikha, Gumba and Pugmo village areas in the season. However, the Hay making pattern of this area is traditional and not so systematic as the people have little knowledge and less interest about it.

\section{Fuel-wood and Timber Harvesting}

The Kunasa area located above $4000 \mathrm{~m}$, is basically the treeless zone but in some south-north faced slopes of Bankal, Talgera, Pangdang and Pangsung pasture lands a few patches of forests are existed. The timber and firewood are extracted from these patches of forests and further low elevated forests of Phu and Punikha monastry areas. Mainly, the tree shrub species like Betula utilis, Rhododendron campanulatum, Cedrus deodara, Abies spectabilis, Pinus wallichiana, Salix species., Potentilla peduncularis, Juniperus squamata, J. indica etc. are utilized for firewood needs. The collection of timber is not frequently done as the repairing and construction of houses and sheds is needed only after long periods of years. But firewood collection from the forests and bushes is quite frequent for daily needs. In different sub-pastures such firewood collection is done separately in each. Thus, the harvesting intensity is not in a particular area but remarkably scattered in different pasturelands. In this area, an approximate 30-40 Bhari (a bundle of $40 \mathrm{~kg}=1$ Bhari) of firewood is collected and stored by each family in the season. According to the Lamas, for construction purpose timber is obtained from dead trees that are either naturally dead or uprooted by landslide and snowstorm. The collection period is not specific but the herdsmen collect these things along their arrival at Kunasa for cropping in the late May until their downward movement to the village in the mid-October. During this period, the time of collecting these things is not also tentative but largely depends upon their leisure while grazing the herds in the pasture and sub-pastures especially in the day time.

\section{Thatching Material Harvesting}

The harvesting of thatching materials is done mainly for repairing and roofing the houses of Kunasa settlements and semi-permanent sheds of sub-pastures. The repairing of houses is not done yearly but the sheds are to be roofed yearly, therefore, thatching materials are mainly harvested for sheds roofing purposes. Under this harvesting pattern, primarily barks, leaves, and small timber are harvested before the rainy season, especially before the livestock Goths shift to sub-pastures by the 
end of June. The barks and branches of Betula utilis are widely extracted for roofing the sheds from the adjoining patches of forests of the pasture and sub-pastures. The herdsmen who utilize the summer sub-pastures of Kunasa pasture mainly do this type of pasture harvesting. As the existent system of joint housing and roofing a shed by $4-5$ families, the need of thatching materials is naturally of small quantity and not intensive.

\section{Operational Rules of the Gumba System for Pasture Resource Management}

The Lama Tetton Molan Gyaljan, known as the Lama of high knowledge regarding the landscapes, climate, biodiversity, natural resources and the environment as a whole, had made various rules and regulations for the better management of natural resources including the pasture resource. Over the generations, these rules have been in operation but not much modified since they are well adapted to such a geo-physical and climatic condition of the areas. During the field study these rules were not found in written form, but the Lama, and more elderly herders of the Pugmo village who seasonally graze their livestock in the Gumba area know the traditional rules of the Gumba system. According to them, most of the rules were existed even today which are transmitted from generations verbally. Some of the traditional rules enumerated by the Lamas and elder people are as follows.

1. To graze the herds only in the particular pasture areas and sub-pastures where the herdsmen have been grazing their herds over the generations.

2. Not to dig out the land in the communal pastures and sub-pastures if the herdsmen are not constructing temporary houses or sheds for shelter.

3. Not to extend the individual land areas in the communal pastures for agricultural purposes.

4. Not to set fire in the pasture lands in order to protect pasture products; forage, trees, medicinal and other various plant species and wildlife.
5. Not to whistle and cry loudly in the pasture and subpastures for not disturbing the wildlife.

6. Not to cultivate medicinal plants in the community owned pasture lands for the individual purposes.

7. Except for basic household need, various species of medicinal plants should not be harvested from the natural ecosystem and if they have to harvest the plants, areas where the plants are dominant should be selected.

8. The fodder trees and other palatable bushes if they are present in the community owned pastures are not to be cut down.

9. Not to cut down tree in the forest/pasture lands, during the restricted period that is from 15 March to 15 December, for the healthier germination and growth of plant species

10. For timber extraction, a formal permission is to be asked with the Lamas specifying the purpose, tree species, quantity needed and including the Raita (small piece of cloth that is religiously offered to the gods and Lamas) royalty for that ${ }^{6}$.

11. To worship trees with offering the food grains and Raita prior to fell the trees from forest pasture areas as to show cultural and religious respect to forest/pasture resources.

12. The Lamas should generally allow to cut-down the dead trees especially in the area where the specific species are dominant.

13. The Tabas are to be sent out for cross-checking, whether or not the applicants' are performing as per the permission.

14. To check and control the entrance and encroachment of outsiders within the Lama managed Gumba area, for livestock grazing and pasture products harvesting.

${ }^{6}$ Generally the royalty was pre-determined as Rs. 1 for small trees and Rs. 5 for large trees. Those who lacked cash money could deposit utensils for certain period (after paying the royalty utensils could be returned) and offer food grains instead of cash money. The fund created by such royalty collection, used to be spent in performing religious tasks in the Gumbas and other social services; beaten tracks and bridges construction and Gumba repairing etc. 
15. The herders should create good understanding and cooperation among themselves while grazing the herds in the pastures and sub-pastures and using the resources.

16. To graze the livestock only as cross-out in the pastures and sub-pastures of the Goth moving routes such as Kunasa, Pangsung and Talgera.

17. The herdsmen should report to the Tabas and Lamas if any users whether insider or outsider violated the norms regarding the pasture resource management.

18. Grazing in the cropping and other pasturelands should be made effective only when the harvesting of crops is completed and restriction on pasturelands is opened.

19. To ask permission with the owner for resources use (Fodder, firewood, thatching materials etc.) in case of the resources are located in the private lands.

20. To determine the date of upward-downward and inwardoutward movements of livestock Goths at the herdsmen level and at the appropriate time.

21. The harvesting of pasture products, fodder grass, tree fodder, medicinal plants, etc, are to be done only when the Lamas announce the date for public harvesting: that are especially after the 'Thanshing Richi' in the months of September.

Regarding the rules, the Lamas have informed that they can make new rules of control and maintaining the resources even today if they thought essential. For instance, since three years they made a new rule to restrict the 'Dama Ban' for grazing the herds between October-February for substantial regeneration of plant species, as there were signs of overgrazing. The rules mentioned above are primarily operational, regulative, and prohibitive types in nature. Presently even after the implementation of SPNP and end of the Talukdari system, most of the rules are existing and are maintained indigenously by the Lamas with the help of Mukhiya and people.

\section{Decision-Making}

The decision making, within the communal pasture resource management system is one of the key aspects as it affects the whole system both in short-run and long run. Keeping this fact in mind, the Pugmo herders carefully make decisions only in less effective issues to others or the system. If the issues are of communal types where to graze the herds, when to graze, when to enter and exit in a particular pasture area and subpasture, where from the pasture harvesting, when to perform Kulysa and Lamachhumik Pujas etc, the farmers see and wait for mutual and informed persons' decisions that are made in assembled group level. But on the contrary, if the issues are related to individual households such as; how much and which species of livestock to keep, where to live, which member goes for summer grazing, to whom to ask for help for the herds grazing etc, the farmers make decisions either individually or at household level.

The farmers have also reported that gender awareness and non-discrimination is remarkable in this area and therefore, the decisions are not made on the basis of gender. However, there are a few tasks generally identified for women like household chores, summer herding, fodder grass and firewood collection, helping Lamas while collecting the medicinal plants etc., and in such issues, the females themselves make the decisions. Similarly, in the tasks generally identified for men, such as shed making and repairing, thatching material collection, roofing, timber harvesting, cropping management, etc., The decisions are made by the males. If there is absence of household head in a particular family, the decisions about such issues are naturally made by the immediate elder persons and the gender discrimination is considered minor and often neglected. However, the role of Lamas and Mukhiya in overall decisionmaking in the village especially in common issues are considered significant. This is because they are expected to guide and help the people. Their advisory decisions are respectfully followed and obeyed by the people who think of them as the most knowledgeable people in the society. At present, the formation of Sisters' Group has empowered the women of Pugmo village. Thus, they have started to involve themselves in decision making process in the communal and social issues getting ahead of household and family level. 


\section{Labor Mobilization}

The labor mobilization for the tasks related to the pasture resource management is generally based on the leisure, capacity and knowledge of the individual members of a given family or the community as well. In this area, the division of labor is less defined in terms of gender in a family. So the free members from the farming, income generating activities and household chores are drafted to do pasture related tasks. But those individuals of specific skill and knowledge like shed makers, medicine maker Amchis etc., are particularly expected to contribute their labor and knowledge to the wellbeing of families and society. Besides, the labor mobilization pattern can be characterized in terms of seasons and levels that are; summer grazing management and pasture harvesting. The summer grazing management related tasks are the routine tasks so in it regular type of labor is mobilized. The females especially girls, at least one person from each livestock owned households are usually mobilized to the Kunasa summer pasture area. In question why they primarily mobilize female manpower? Their natural answers were; the area is safe geographically, Holy Land regularly guarded by Lamas and Tabas, and also because of the lack of male manpower being involved in Trams-Himalayan trade. However, one or two males among from the herders remain there for the assistance to the females.

In the same way, for pasture harvesting in the summer pastures, the labor use pattern is different, as the Lamas are mainly involved as informed persons. The women remain in the high elevated Kunasa pasture for grazing their livestock in the summer season, assist the Lamas in their harvesting activities. Such labor mobilization is not their routine work but are seasonally needed in the summer months and therefore, is always intensively required for few days with $10-15$ hours time spent in a day. Notably, the trends of employing hired labor for such tasks or activities were not found in the study area. But cooperative labor use is commonly asked with relatives and neighboring herdsmen if a particular family has less manpower supply. This system of labor mobilization is typically done on voluntary basis but in return substantial foods like flour of wheat, potatoes etc., are provided as the gift to the herders by the livestock owners.

\section{Conflict Resolution}

Under the control of Lamas, within the Gumba area, there appears good cooperation and understanding among the Pugmo herders hence pasture consumption and management related activities are running smoothly. Even so, the area is not free from disputes and conflicts regarding the pasture resource management because in the past, people have experienced some disputes and conflicts. Primarily, the conflicts or disputes have occurred there either by the outsiders' intervention into the Pugmo territory or pasture consumption and management related issues: grazing, harvesting, rule breaching etc. As per their traditions and knowledge, the problems were resolved with the mutual role of Lamas, Mukhiya, Tabas, Toremas and people. With the changing issues or problems the resolution measures or processes were refined and modified over the generations which have been their traditional norms and values by which aroused conflicts are resolved at present also.

The internal process of disputes or conflicts resolution regarding the pasture resource management in this area is quite systematic even in absence of formal institution. As in welldeveloped institutions, hierarchic power structure and step wise process are adopted for the conflict resolution. Generally, the disputes occurred at individual as well as user group levels are amicably negotiated among the herdsmen themselves. If negotiations do not materialize or the people are unable to settle the cases themselves that is referred to the Lamas of Gumba, Pugmo village, for the final resolution. The then Lamas in consultation with the Tabas, Mukhiya and concerned herdsmen, examine the case with blaming and claiming issues and solve the case at the assembled group level with certain naming. While setting the case, the Lamas base their decisions under the rules made by their ancestors regarding the natural resources management. As a result, the real offender is either excused or 
fined as per the nature and severity of crime ${ }^{7}$. In this regard, it is to be noted that if the main Lama is absent in the village, busy in religious functions and other tasks, the conflicts are resolved in the mutual leadership of the Assistant Lama, Junior Lama and Mukhiya, by adopting the same process. But the resolution process in case of outsiders' intervention within their territory is a bit different that generally, all people including Lamas and Mukhiya protest against the intervention, dialogue with the encroachers and maintain understanding. The Lamas have reported that previously in the Rana regime few influential persons of Tripurakot and Mustang had entered within the Gumba territory for wildlife poaching but they were returned back without doing such activites because the Lamas and locals showed their traditional rules against poaching the wildlife there. Similarly, the Saldang herders were chased with their herds while entered there for grazing their livestock into the territory. However, even after the inception of SPNP, the park authority has not experienced the violation of park regulations by the Pugmo people and therefore, no action against violation were recorded.

\section{Conclusions}

This study area has a traditional religious organization for control and maintaining of natural resources which is known as the Gumba system. The system is existent with its operational rules and the control system of Lama hierarchic structure. Being guided by the Bonpo religious philosophy and having cultural associations with the landscapes, forests, pastures, and other plant resources, the people utilize the natural resources including the pastures resource under the cultural and religious contexts: permission, respect and limitations. Therefore, the studied Gumba system of pasture resource management of this area is largely effective. So there is not an urgency of formal

\footnotetext{
7 Generally fine is levied; Rs. 100 for both insiders and outsiders in general cases, where whereas in repeated cases the amount is doubled (Rs. 200). Similarly, in severe cases; such as firing, fire felling the trees hunting by outsiders and other rule breaching etc., fine is levied 500 Rs. for initial cases and in repeated cases, the fine is doubled (1000 Rs.) and so on.
}

organization like the users committee. But the study area being located within the SPNP area the park has been implementing its rules, restrictions and development programs and thus, in the future the park might make further intervention and the existing religious and cultural sets of norms, values, rules and regulations might be disturbed. Consequently, there may be a situation of park and people conflict. To avoid the possible tension situation and give continuity to the effective Gumba system of pasture resource management a special consideration in preserving its traditional norms, values and philosophy should be made for successful achievements. On the other hand, the Gumba system and its rules of rotational and deferred livestock grazing with specific herder's groups and specified access of each group in the pastures, and Amchis' knowledge and cultural dimension of medicinal plants harvesting are systematic and sustainable from equitable resource allocation and utilization perspectives. Thus these patterns of grazing should be maintained. Such a system is not only unreported before but also unique example of cultural dimension of pasture resource management in Nepalese as well as world's context. Therefore, the system and rules are to be regarded while making any management plans for this area and brought to the knowledge of the conservationists and the general people by the media for illustrative overview.

\section{REFERENCES}

Archaya, H.P. 1990

Processes of Forest and Pasture Management in a Jirel Community of Highland Nepal. Unpublished Ph.D. dissertation in Anthropology. Cornell University, Ithaca.

Archer, A.C. 1985

Nepal High Altitude Pastures and Their Development in the Border Districts. Report NEP/85/97 Kathmandu: FAO.

Ariol, Philip

1979
Transhumaning Animal Husbandry System in Kalingchok Region, Central Nepal. SATA, Kathmandu. 
Devkota, P.L. 1992

Traditional Systems of Forest and Pasture Management from Central Nepal, Report series 21, HMG, Ministry of Agriculture / Winrock International.

Dhakal, N 1998

Bascline Survey Report of Mountain Area Conservation Project in Shey Phoksundo National Park Area. Unpublished report, WWF Nepal.

Dhungel, B.P. 1987

Socioeconomic and Legal Arrangements for Grazing on Public Land : Case Study of Bahadurganj. Natural Resource management Series, No. 11. HMG-USAID-GTZ-IDRC-FORD WINROCK Project, Kathmandu.

Dutt, P. 1985

"The Utilization of Natural Grasslands in the Mountain Areas of Nepal" in Livestock in the Hills of Nepal (I). A.M. Morel and K.P. Oli, eds. Pakhribas Agricultural Centre, Dhankuta. Pp. 13846.

Manal, P. 1990

Pastureland and Livestock Grazing in Shey Phoksundo National Park, Dolpa: Unpublished report. National Pasture and Fodder Research, Kathmandu.

Mcknight, M.W. 1997

Indigenous Rangeland, Management in High Altitude Nepal : A Case Study in Pugma Village, Dolpa. Unpublished research report submitted to University of Wisconsin-Madison Collage, U.S.A.

Miller, D.J. 1993a.
Rangelands in Northern Nepal : Balancing Livestock Development and Environmental Conservation. USAID. Kathmandu.
Miller, D.J.

$1993 b$.

Niamir, M.

1995

High Elevation Rangeland in the Himalaya and Tibetan Plateau: Issues, Perspectives and Strategies for Livestock Development and Resource Conservation. Presented at the XVII International Grassland Congress, February 13, 1993. Lincoln University, Christchurch, New Zealand.

Indigenous Systems of Natural Resource Management among the Pastoralists of Arid and Semi-Arid Africa, in D.M. Warren, L.J. Slikkerveer and D. Brokensha (ed.), The Cultural Dimension of Development: Indigenous Knowledge Systems, London: Intermediate Technology Publications, pp. 245-256.

Parajuli, D.B.

1996

Pasture Resource and Livestock Management in Walung Village of Makalu Barun, National Park and Conservation Area. Unpublished Research Report, Submitted to M.B.C.P., Kathmandu, Nepal.

Rai, N.K. and Thapa, M.B. 1993.

Indigenous Pasture management Systems in High Altitude Nepal: A Review. Research Report Series No. 22. HMG Ministry of Agriculture/Winrock International, Kathmandu.

Sanford, S.

1983

Management of Pastoral Development in the Third World. John Wiley and Sons, $316 \mathrm{pp}$.

Sherpa, N.W.

1992

Operational Plan : Shey Phoksundo National Park. World Wildlife Fund Nepal.

Shrestha, K.K., et. al.

1998 Conservation of Plant Resources, Community Development and Training in Applied Ethnobotany at Shey Phoksundo National Park and its Buffer Zone, Dolpa. WWF, Nepal, Report series 33. 
Thapa, M.B.

1990

People's Participation in Range Management : The Case of Mustang, Nepal. Unpublished MS Thesis in Rural Sociology. University of Philippines at Las Banos.

Upadhaya, S.R.P

1995

Nepals' Social, Economic and Administrative History Ratna Pustak Bhandar, Kathmandu, Nepal.

Von Furer-Haimendorf, C.

1975 Himalayan Traders. John Murray, London.

Wilson, $\mathrm{P}$.

1981

Ecology and Habitat Utilization of Blue Sheep in Nepal. Biological Conservation. 21:55-74.

Mc VEigh, C. 1994
Indigenous Resource Management Systems Among the Tibetan-speaking Herders in Western Nepal. Research Report Submitted USAID Nepal Mission, Kathmandu, Nepal.

\section{EMERGING METHODS IN RESEARCH PARTICIPATION AND EMPOWERMENT PROCESSES IN NEPAL}

Philip Tanner*

\section{Introduction}

This paper is divided into two discussions. Firstly, it traces the development of participatory processes and policy in Nepal's development evolution over the past 40 years. Secondly, it examines, briefly, the developments in international social research and emerging knowledge on the subject of participation and empowerment concepts that may influence the direction of social research in Nepal.

\section{The Emergence of Participation in Nepal}

At the time of Nepal's emergence onto the global scene, over $93 \%$ of its population earned its livelihood from the land. The new rulers, after 1951, were eager to project themselves as the champion of the poor, the downtrodden and the oppressed (Lohani, 1978) and discussion of "democracy" abounded. Struggling to develop a comprehensive development plan, it was clear that most effort had to focus on rural and agricultural development programmes. However, by 1979, a study on Nepal's agrarian problems described the strategies and programmes for their solution as "merely a survival strategy" (Blaikie, M, Cameron, J \& Seddon, D., 1979). Clearly, the efforts of the state were not directly manifest in field practice. Generally, there was acceptance in Nepal's academic and government community that rural development efforts

Dr. Philip Tanner worked for UNDP in Nepal from 1990-92 and subsequently carried out extensive research in Nepal during the period of 1993-1997 on the relationship of Empowerment and Participatory development concepts in Nepal. He is now working in a development INGO in Nepal. This is the first in a series of articles on empowermnet theory in the Nepali context 